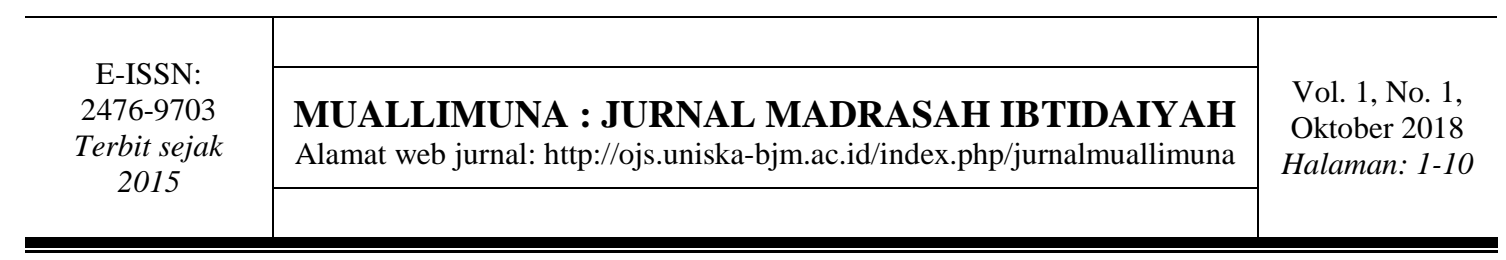

\title{
EFEKTIVITAS MODEL PEMBELAJARAN KOOPERATIF STAD TERHADAP HASIL BELAJAR KOGNITIF DAN DAYA RETENSI SISWA KELAS V SEKOLAH DASAR
}

\author{
Yudha Adrian', Sa'adah Erliani ${ }^{2}$ \\ Program Studi PGSD, STKIP PGRI Banjarmasin \\ ${ }^{1}$ yudhaadrian@stkipbjm.ac.id, ${ }^{2}$ saadaherliani@ stkipbjm.ac.id
}

\begin{abstract}
Abstrak: Penelitian ini bertujuan untuk: 1) mengetahui efektivitas model pembelajaran kooperatif STAD terhadap hasil belajar kognitif siswa kelas V Sekolah Dasar; 2) mengetahui efektivitas model pembelajaran koooperatif STAD terhadap retensi siswa kelas V Sekolah Dasar. Penelitian ini menerapkan pendekatan Quantitatif, dengan metode Non Equivalent Kontrol Group Design. Subjek penelitian berjumlah 52 orang siswa kelas 5 SDN Kelayan Barat. Penelitian ini terdiri atas dua kelas: 1) kelas eksperimen menerapkan model pembelajaran kooperatif STAD; 2) kelas kontrol menerapkan pembelajaran konvesional. Instrumen yang digunakan adalah tes pilihan ganda berjumlah 30 item. Analisis data penelitian ini menggunakan uji t independent berbantuan SPSS 20. Hasil penelitian menunjukkan bahwa model pembelajaran kooperatif efektif memberikan pengaruh terhadap hasil belajar kognitif siswa kelas V Sekolah Dasar dan daya retensi siswa. Hal ini ditunjukkan melalui hasil analisis uji $\mathrm{t}$ independent posttest 1 menggunakan uji $\mathrm{t}$ independent menunjukkan nilai thitung -3,73 dengan nilai signifikansi. $0,00<0,05$ sehingga $\mathrm{H}_{0}$ ditolak. Selajutnya, analisis data posttest 2 menggunakan uji $\mathrm{t}$ independent menunjukkan nilai t hitung $-3,65$ dengan nilai signifikansi. $0,001<0,05$ sehingga $\mathrm{H}_{0}$ ditolak. Prosentase penurunan daya retensi siswa kelas eksperimen sebesar $3 \%$, sedangkan penurunan daya retensi siswa kelas kontrol sebesar 5,1\%. Selisih penurunan daya retensi antara kelas eksperimen dan kelas kontrol sebesar 2,1\%. Dengan demikian, kelas eksperimen lebih baik dibandingkan kelas kontrol dalam mempertahankan daya retensi.
\end{abstract}

Kata Kunci: pembelajaran kooperatif; STAD; hasil belajar kognitif; daya retensi

\section{THE EFFECTIVENESS OF COOPERATIVE LEARNING STAD TOWARD STUDENTS' OUTCOME AND RETENTION OF GRADE 5TH ELEMENTARY $S C H O O L$}

Abstract: The aims of this study are to : 1) find out effectiveness cooperative learning STAD toward grade 5th students' outcome; 2) find out effectiveness cooperative learning STAD toward student's retention. This study implemented Quantitative study in non-equivalent control group design. Subject of study are 52 students of 5th grade in SDN Kelayan Barat. This study consist of two group. First group is experimental class. Second group is control class. In experimental class implemented cooperative learning STAD. In control class implemented traditional learning. Instument of study is multiple-choices test that is consist of 30 items. Data of study 
analized by independent $t$ test on SPSS 20. Findings of study were showed that cooperative learning STAD more effective toward student's outcome and retention. Statistic analiysis of posttest 1 showed that $t$ value $-3,73$ or p.value $0,00<0,05$, so $H_{0}$ is rejected. Then, statistic analiysis of posttest 2 showed that $t$ value -3,65 or p.value 0,001 $<0,05$, so $H_{0}$ is rejected. The retention of experimental class was decreased about 3\%, whereas control class was decreased about 5,1\%. It means that experimental class was better to keep after memories than control class.

\section{Keywords: cooperative learning; STAD; students' outcome; students' retention}

\section{PENDAHULUAN}

Ilmu Pengetahuan Sosial yang disingkat dengan IPS merupakan mata pelajaran wajib yang diselenggarakan di tingkat Sekolah Dasar. Mata pelajaran ini salah satu mata pelajaran wajib yang terstruktur pada kurikulum 2013. Oleh karena itu, mata pelajaran IPS wajib dipelajari oleh siswa dari kelas 4 sampai kelas 6 Sekolah Dasar.

Mata pelajaran IPS merupakan turunan dari beberapa disiplin ilmu-ilmu sosial yang telah berdiri sendiri. Mata pelajaran IPS adalah penyederhanaan konsep dari disiplin ilmu Georgrafi, Sejarah, Sosiologi, Antropologi, dan Ekonomi yang disederhanakan dalam satu bidang kajian. Kajian pada mata pelajaran IPS disesuaikan dengan kemampuan, intelegensi, psikologi, dan pemahaman siswa di tingkat Sekolah Dasar. Kajian dasar mata pelajaran IPS di Sekolah Dasar mengkaji seperangkat peristiwa, fakta, konsep, dan generalisasi pengetahuan yang dikaitkan dengan problematika atau isu-isu sosial yang berkembang di ruang lingkup masyarakat regional, nasional dan internasional.

Tujuan pembelajaran IPS untuk memperkenalkan siswa tentang pengetahuan yang berkenaan dengan kehidupan masyarakat atau manusia secara sistematis (Suhanandji \& Wasdopo, 2003). Berdasarkan pendapat tersebut maka setiap siswa dapat dipahami bahwa siswa harus memperlajari materi-materi tentang sosial harus sistematis. Siswa diajarkan mengenai pengetahuan yang paling sederhana mengarah kepada pengetahuan yang lebih rumit. Dengan kata lain, siswa tidak diperkenankan menerima pengetahuan secara acak atau tidak tersistematis.

Lebih lanjut menurut (Wahidmurti, 2017) tujuan utama mempelajari IPS agar membantu siswa menjadi warga negara yang baik guna melalui pengambilan keputusan yang rasional berdasarkan informasi publik atau umum dari masyarakat secara demokratis dan budaya yang beragam di dunia yang saling kergantungan. Hal ini tidak jauh berbeda dengan pernyataan sebelumnya. Idealnya siswa diberikan pelajaran tentang hal-hal yang paling sederhana terlebih dahulu. Selanjutnya, siswa diajarkan dengan situasi atau materi-materi yang lebih kompleks sesuai dengan kemampuan berpikir siswa. Hal ini mengisyaratkan bahwa, seorang guru idealnya terstruktur dalam mentransfer pengetahuan kepada siswa.

Pengorganisasian materi pada mata pelajaran IPS di Sekolah Dasar mengacu pada struktur kurikulum. Undang-Undang Sisdiknas no.20 (2003) kurikulum merupakan seperangkat rencana dan pengaturan mengenai tujuan, isi, dan bahan pelajaran, serta cara atau metode yang digunakan sebagai pedoman penyelenggaraan kegiatan pembelajaran untuk mencapai tujuan tertentu. Setiap kegiatan pendidikan yang dilaksanakan di Sekolah Dasar harus mengacu dan berpedoman pada kurikulum. Oleh karena itu, pengorganisasian mata pelajaran IPS di Sekolah Dasar harus berpedoman pada kurikulum. 
Secara umum, di Sekolah Dasar telah menerapkan kurikulum 2013. Penerapan kurikulum tersebut disesuaikan dengan kesiapan di tingkat satuan pendidikan. (Rusman, 2015) menyatakan bahwa pada kurikulum 2013 kegiatan pembelajaran di Sekolah Dasar kelas I sampai VI dilakukan dengan menggunakan pembelajaran tematik terpadu. Pembelajaran tematik terpadu merupakan kegiatan pembelajaran yang memadukan beberapa mata pelajaran yang diintegrasikan melalui tema-tema tertentu. Terkait dengan penerapan pembelajaran tematik terpadu, maka mata pelajaran IPS disekolah Dasar disusun secara terpadu diintegrasikan dengan mata pelajaran lain yang sesuai dengan karakteristik mata pelajaran IPS.

Perpaduan mata IPS pada kurikulum 2013 tidak mengurangi esensi konten mata pelajaran IPS tersebut. Melainkan, kegiatan pengorganisasian materi atau mata pelajaran secara integrated dilaksanakan untuk mencapai tujuan tertentu. Integrasi tersebut diciptakan dengan memusatkan pada masalah tertentu dengan diikat menggunakan tema tertentu (Wahidmurti, 2017). Perpaduan mata pelajaran IPS dengan mata pelajaran lain, secara sederhana agar mempermudah guru menyampaikan materi-materi sesuai dengan kemampuan siswa. Dengan kata lain, keluasan dan kedalaman materi mata pelajaran IPS pada pembelajaran tematik terpadu lebih mudah dipahami berdasarkan kemampuan siswa.

Pembelajaran IPS terintegrasi dalam pembelajaran tematik terpadu idealnya terlaksana secara interaktif, inovatif, dan menyenangkan. Mengacu pada Permen no. 22 (2016) proses pembelajaran pada satuan pendidikan diselenggarakan secara interaktif, inspiratif, menyenangkan, menantang, memotivasi pesertadidik untuk berpartisipasi aktif, serta memberikan ruang yang cukup bagi prakarsa, kreativitas, dan kemandirian sesuai dengan bakat, minat, dan perkembangan fisik serta psikologis peserta didik. Pelaksanaan kegiatan pembelajaran yang menyenangkan, inovatif, dan interaktif dibarengi dengan model, strategi dan metode pembelajaran yang sesuai dengan karakteristik siswa khususnya siswa di Sekolah Dasar. Model, strategi, dan metode yang merangsang siswa untuk aktif dalam kegiatan pembelajaran.

Hasil studi pendahuluan yang dilaksanakan di SDN Kelayan Barat, diketahui bahwa kegiatan pembelajaran masih berpusat pada guru (teacher centered learning). Guru mendominasi kegiatan pembelajaran di kelas. Guru masih berperan menjadi sumber belajar utama pada kegiatan pembelajaran. Padahal, setiap siswa sudah memperoleh buku siswa yang telah di distribusikan oleh pemerintah. Guru mendominasi kegiatan pembelajaran dengan berceramah kepada siswa. Hal ini bertolak belakang dengan esensi kurikulum 2013 yang menghendaki proses pembelajaran aktif, inovatif, dan mengenangkan.

Menyikapi hal tersebut, maka peneliti menawarkan solusi guna mengurangi dominasi guru dalam kegiatan pembelajaran di kelas. Solusi tersebut dengan membuat siswa lebih aktif dalam kegiatan pembelajaran. Dalam hal ini siswa dijadikan subjek belajar di dalam kelas. Perubahan siswa menjadi subjek memerlukan inovasi dan strategi tertentu dalam melaksanakan kegiatan pembelajaran. Dengan kata lain, guru harus menerapkan model, strategi, dan metode pembelajaran yang berorientasi pada siswa (student centered learning).

Salah satu model pembelajaran yang berorientasi pada siswa (student centered learning) adalah model pembelajaran kooperatif STAD (Student Team Achievement Division). Model pembelajaran ini merupakan salah satu model pembelajaran yang dikembangkan oleh Robert Slavin. Model pembelajaran kooperatif STAD berlandaskan teori belajar kontruktivistik kognitif dan konstruktivistik sosial. Dalam kegiatan 
pembelajaran kooperatif STAD terjadi perubahan fokus pembelajaran yang awalnya dari guru menjadi fokus pembelajaran berfokus kepada siswa. Dengan kata lain, dominasi guru dalam kegiatan pembelajaran dalam dikurangi sehingga siswa lebih aktif dalam kegiatan pembelajaran.

Penerapan model pembelajaran kooperatif STAD merupakan kegiatan pembelajaran yang dilaksanakan secara berkelompok. Siswa didorong untuk berpartisipasi dalam kegiatan belajar secara berkelompok dengan teman satu kelompoknya. Hal ini senada dengan pola pikir kurikulum 2013 diantaranya: a) kegiatan pembelajaran dilaksanakan secara interaktif artinya ada hubungan timbal balik antara guru dan siswa; B) Pola pembelajaran sendiri menjadi kegiatan pembelajaran berkelompok (Widyastono, 2013). Melalui kegiatan pembelajaran kooperatif STAD akan merealisasikan pola pikir kurikulum 2013 dan mengakomodasi siswa menjadi lebih aktif dalam kegiatan pembelajaran. Dengan demikian, kegiatan pembelajaran akan lebih efektif dan efisien menggunakan model pembelajaran kooperatif STAD.

Efektivitas model pembelajaran kooperatif STAD telah terbukti secara empiris melalui pelaksanaan penelitian sebelumnya. Hal ini merupakan fakta pendukung yang menyatakan bahwa model pembelajaran kooperatif STAD efektif di terapkan pada kegiatan pembelajaran di sekolah. Thurston, dkk (2010) melaporkan hasil penelitian longitudinal selama dua tahun pada siswa Sekolah Dasar di daerah perkotaan dan pedesaan. Hasil penelitian tersebut menunjukkan bahwa model pembelajaran kooperatif efektif meningkatkan hasil belajar siswa. Hasil penelitian Hafid \& Makkasau (2013) menunjukkan keberhasil peningkatan hasil belajar kognitif dan aktivitas siswa di kelas VI Sekolah Dasar. Dengan kata lain, model koperatif STAD efektif diterapkan di Sekolah Dasar.

Berdasarkan paparan di atas, dapat disimpulkan bahwa solusi yang akan diterapkan pada kegiatan pembelajaran yaitu dengan menerapkan model pembelajaran kooperatif STAD. Penerapan model pembelajaran ini diharapkan (Suhanandji \& Wasdopo, 2003) dapat memberikan pengaruh yang signifikan terhadap hasil belajar siswa. Selain itu, dapat memberikan pengetahuan yang bermakna bagi siswa. Pengetahuan yang bermakna akan membekas pada memori siswa sehingga pengetahuan tersebut akan tersimpan lebih lama pada diri siswa.

\section{METODE}

Penelitian ini menerapkan pendekatan quantitatif. Metode penelitian yang diterapkan pada penelitian ini adalah quasi eksperimen / eksperimen semu. Metode ini terapkan, karena peneliti di dapat mengontrol sepenuhnya variabel penelitian. Desain penelitian ini menerapkan desain nonequivalent control group design. Subjek pada penelitian ini adalah siswa kelas $\mathrm{V}$ yang berjumlah 52 orang yang terdiri atas kelas paralel. Kelas eksperimen terdiri atas 26 siswa dan kelas kontrol terdiri atas 26 siswa. Kelas eksperimen menerapkan model pembelajaran kooperatif STAD sedangkan kelas kontrol menerapkan pembelajaran konvensional.

Desain penelitian yang diterapkan pada penelitian ini ditunjukkan pada tabel di bawah ini:

Tabel 1 Desain Penelitian Nonequivalent Control Group Design

\begin{tabular}{cccc}
\hline Kelas & Pretest & Treatment & Posttest \\
\hline Eksperimen & $\mathrm{O}_{1}$ & $\mathrm{x}$ & $\mathrm{O}_{2,} \mathrm{O}_{3}$ \\
\hline Kontrol & $\mathrm{O}_{4}$ & & $\mathrm{O}_{5}, \mathrm{O}_{6}$ \\
\hline
\end{tabular}

(Sumber: Sugiono, 2013) 
Keterangan:

$\mathrm{O}_{1}=$ Pretest kelas eksperimen

$\mathrm{O}_{4}=$ Pretest kelas kontrol

$\mathrm{X}=$ treatment

$\mathrm{O}_{2}=$ posttest kelas eksperimen pertama

$\mathrm{O}_{3}=$ posttest kelas eksperimen kedua

$\mathrm{O}_{5}=$ posttest kelas kontrol pertama

$\mathrm{O}_{6}=$ posttest kelas kontrol kedua

Instrumen penelitian berupa tes pilihan ganda yang berjumlah 30 soal. Instrumen ini digunakan untuk pretest dan posttest. Instrumen ini divalidasi oleh ahli materi. Selanjutnya, instrumen tersebut diuji cobakan kepada siswa Sekolah Dasar kelas V. Tujuan validasi ahli dan ujicoba lapangan bertujuan agar instrumen tersebut valid untuk mengukur kemampuan kognitif siswa.

Pretest dilaksanakan sebelum pelaksanaan pembelajaran berlangsung. Setelah pretest dilaksanakan, maka dilaksanakan perlakuan/treatment di kelas eksperimen dengan menerapkan model pembelajaran kooperatif STAD. Sedangkan di kelas kontrol diterapkan pembelajaran konvesional. Setelah perlakukan/treatment dilaksanakan, maka siswa diberikan posttest. Posttest diberikan sebanyak 2 kali. Posttest pertama dilaksanakan untuk mengetahui hasil belajar siswa setelah memperoleh perlakuan. Selanjutnya, satu minggu setelah posttest 1 siswa diberikan posttest 2 untuk mengetahui daya retensi siswa.

Hasil pretest, posttest 1 , dan posttest 2 dilakukan uji normalitas. Selanjutnya, data tersebut diuji homogenitas. Jika data sudah normal dan homogen, maka data tersebut dianalisis menggunakan uji t independent berbantuan SPSS 20. Analisis perbandingan kemampuan kognitif kelas eksperimen dan kelas kontrol untuk mengetahui efektivitas model pembelajaran STAD terhadap siswa kelas V. Analisis yang dilakukan untuk mengukur daya retensi siswa dilakukan dengan melihat rata-rata nilai posttest 1 dan posttest 2 dari masing-masing kelas.

\section{HASIL DAN PEMBAHASAN \\ HASIL}

Pelaksanaan penelitian di SDN Kelayan Barat dari kelas eksperimen dan kontrol. Kelas eksperimen diterapkan model pembelajaran STAD. Kelas kontrol menerapkan pembelajaran konvensional. Subjek penelitian pada penelitian ini berjumlah 52 orang siswa. Data pada penelitian terdiri atas tiga bagian yaitu:

1. Pretest dilaksanakan di kelas eksperimen dan kelas kontrol. Pretest dilaksanakan untuk mengetahui kemampuan awal siswa sebelum diberikan perlakuan. Selain itu, pretest dilaksanakan untuk mengetahui normalitas dan homogenitas populasi.

2. Posttest 1 dilaksanakan bertujuan untuk mengetahui kemampuan siswa setelah diberikan perlakukan. Selain itu, posttest 1 dilaksanakan untuk mengukur perbedaan hasil belajar siswa. Melalui pengukuran hasil posttest 1 maka dapat disimpulkan efektivitas perlakuan di kelas eksperimen dan kontrol.

3. Posttest 2 dilaksanakan untuk mengetahui daya ingat siswa terhadap materi yang telah dipelajari oleh siswa. Pada penelitian ini, daya ingat siswa dikenal dengan istilah retensi. Daya retensi siswa diuji menggunakan soal pilihan ganda. Pelaksanaan tes retensi ini dilaksanakan satu minggu setelah posttest 1 dilaksanakan. Tujuan posttest 2 atau tes retensi dilaksanakan untuk mengetahui kemampuan siswa dalam 
mengingat materi yang telah dipelajari sebelumnya. Hasil tes retensi ini dianalisis menggunakan uji t independent untuk mengetahui perbedaan hasilnya. Rata-rata nilai posttest 1 dan posttest 2 dihitung untuk mengetahui daya retensi siswa.

Data hasil pretest dan posttest siswa pada kelas eksperimen dan kontrol disajikan sebagai berikut:

Tabel 2 Rekapitulasi Nilai Pretest, Posttest 1 dan Posttest 2

\begin{tabular}{cccccc}
\hline Pretest & Kelas & $\mathbf{N}$ & Rata-rata & Standar Deviasi & Standa Error \\
\cline { 2 - 6 } & Eksperimen & $\mathbf{2 6}$ & 50,13 & 11,45024 & 2,24558 \\
& & & & & \\
\cline { 2 - 6 } Kontrol & $\mathbf{2 6}$ & 46,54 & 9,9998 & 1,9611 \\
\hline \multirow{2}{*}{ Posttest 1 } & Eksperimen & $\mathbf{2 6}$ & 74,23 & 6,7696 & 1,3276 \\
\cline { 2 - 6 } & Kontrol & $\mathbf{2 6}$ & 66,15 & 8,7278 & 1,7117 \\
\hline & Eksperimen & $\mathbf{2 6}$ & 72,05 & 7,7220 & 1,3276 \\
\cline { 2 - 6 } & Kontrol & $\mathbf{2 6}$ & 62,95 & 10,1252 & 1,7117 \\
\hline
\end{tabular}

Berdasarkan tabel 2 menunjukkan hasil rata-rata nilai pretest, posttest 1 dan posttest 2 . Selisi nilai rata-rata pretest siswa kelas eksperimen dan kontrol 3,59. Selanjutnya, nilai posttest kelas eksperimen lebih tinggi dibandingkan nilai kelas kontrol. Pada posttest 2 nilai rata-rata kelas eksperimen lebih tinggi dibandingkan nilai kelas kontrol. Dengan demikian, nilai kelas eksperimen lebih baik dibandingkan nilai kelas kontrol.

Tabel 3 Hasil Uji Normalitas

\begin{tabular}{lccc}
\hline Pretest & Kelas & Sig & Ket \\
\cline { 2 - 4 } & Eksperimen & 0,322 & $\mathrm{H}_{0}$ diterima \\
\cline { 2 - 4 } & Kontrol & 0,224 & $\mathrm{H}_{0}$ diterima \\
\hline Posttest 1 & Eksperimen & 0,066 & $\mathrm{H}_{0}$ diterima \\
\cline { 2 - 4 } & Kontrol & 0,757 & $\mathrm{H}_{0}$ diterima \\
\hline Posttest 2 & Eksperimen & 0,913 & $\mathrm{H}_{0}$ diterima \\
\cline { 2 - 4 } & Kontrol & 0,287 & $\mathrm{H}_{0}$ diterima \\
\hline
\end{tabular}

Berdasarkan tabel 3 menunjukkan hasil uji normalitas berbantuan SPSS pada ratarata nilai pretest, posttest 1 dan posttest 2 di kelas eksperimen dan kontrol. Pretest kelas eksperimen 0,322>0,05 dan kontrol 0,224>0,05 sehingga $\mathrm{H}_{0}$ diterima. Hal ini menunjukkan data pretest siswa normal. Posttest 1 kelas eksperimen 0,066 > 0,05 dan kontrol 0,757 >0,05, sehingga $\mathrm{H}_{0}$ diterima. Hal ini menunjukkan posttest siswa normal. Posttest 2 kelas eksperimen 0,913>0,05 dan kontrol 0,287>0,05 sehingga $\mathrm{H}_{0}$ diterima. Hal ini menunjukkan posttest 2 siswa normal. Dengan demikian, dapat disimpulkan bahwa nilai pretest, posttest 1 dan posttest 2 berdistribusi normal.

Tabel 4 Hasil Uji Homogenitas

\begin{tabular}{lccccc}
\hline & Levene Statistic & df1 & df2 & Sig. & Ket \\
\cline { 2 - 6 } Posttest 1 & 2,826 & 1 & 50 & 0,099 & $\mathrm{H}_{0}$ diterima \\
\hline Posttest 2 & 0,648 & 1 & 50 & 0,425 & $\mathrm{H}_{0}$ diterima \\
\hline
\end{tabular}

Berdasarkan tabel 4 menunjukkan bahwa hasil uji homogenitas berbantuan SPSS pada rata-rata nilai posttest 1 dan posttest 2 di kelas eksperimen dan kontrol. Nilai signifikansi posttest $10,099>0,05$ sehingga $\mathrm{H}_{0}$ diterima. Hal ini menunjukkan bahwa 
nilai posttest 1 berdistirbusi homogen. Selajutnya, nilai signifikansi posttest $20,425>$ 0,05 sehingga $\mathrm{H}_{0}$ diterima. Hal ini menunjukkan bahwa nilai posttest 2 berdistribusi homogen. Dengan demikian, data posttest 1 dan posttest 2 berdistibusi homogen. Selanjutnya, nilai posttest 1 dan posttest 2 di uji menggunakan uji t independent untuk mengetahui efektivitas model pembelajaran STAD.

Tabel 5 Hasil Uji T Independent Posttest 1

\begin{tabular}{cccccccc}
\hline Posttest 1 & $\begin{array}{c}\text { Levene } \\
\text { Test }\end{array}$ & Sig. & T & Df & $\begin{array}{c}\text { Uji t } \\
\text { Sig. }\end{array}$ & Mean & $\begin{array}{c}\text { Std. } \\
\text { Error }\end{array}$ \\
\hline $\begin{array}{c}\text { Equal variances } \\
\text { assumed }\end{array}$ & 2,826 &, 099 & $-3,729$ & 50 &, 000 & $-8,07731$ & 2,16619 \\
\hline $\begin{array}{c}\text { Equal variances not } \\
\text { assumed }\end{array}$ & & & $-3,729$ & 47,086 &, 001 & $-8,07731$ & 2,16619 \\
\hline
\end{tabular}

Berdasarkan tabel 5 menunjukkan nilai $\mathrm{F}$ hitung levene test 2,83 dengan signifikansi 0,099>0,05 sehingga nilai posttest 1 berdisitribusi homogen. Oleh karena $\mathrm{itu}$, hasil analisis uji $\mathrm{t}$ independent menggunakan equal variances assumed. Selanjutnya, nilai t hitung $-3,73$ dengan nilai signifikansi 0,00 dengan $\mathrm{df}=50$. Oleh karena itu signifikansi $0.00<0,05$ sehingga $\mathrm{H}_{0}$ ditolak. Dengan kata terdapat perbedaan yang signifikan terhadap hasil belajar kognitif kelas eksperimen dan kontrol. Oleh karena itu dapat simpulkan bahwa model pembelajaran kooperatif STAD efektif terhadap hasil belajar kognitif siswa kelas $\mathrm{V}$.

Tabel 6 Hasil Uji T Independent Posttest 2

\begin{tabular}{cccccccc}
\hline Posttest 2 & $\begin{array}{c}\text { Levene } \\
\text { Test }\end{array}$ & Sig. & T & Df & $\begin{array}{c}\text { Uji t } \\
\text { Sig. }\end{array}$ & Mean & $\begin{array}{c}\text { Std. } \\
\text { Error }\end{array}$ \\
\hline $\begin{array}{c}\text { Equal variances } \\
\text { assumed }\end{array}$ &, 648 &, 425 & $-3,645$ & 50 &, 001 & $-9,10308$ & 2,49731 \\
\hline $\begin{array}{c}\text { Equal variances not } \\
\text { assumed }\end{array}$ & & & $-3,645$ & 46,730 &, 001 & $-9,10308$ & 2,49731 \\
\hline
\end{tabular}

Berdasarkan tabel 6 menunjukkan nilai $\mathrm{F}$ hitung levene test 0,648 dengan signifikansi 0,425 > 0,05 sehingga nilai posttest 2 berdisitribusi homogen. Oleh karena itu, hasil analisis uji $\mathrm{t}$ independent menggunakan equal variances assumed. Selanjutnya, nilai $t$ hitung $-3,65$ dengan nilai signifikansi 0,00 dengan $\mathrm{df}=50$. Oleh karena itu signifikansi $0.00<0,05$ sehingga $\mathrm{H}_{0}$ ditolak. Dengan kata terdapat perbedaan yang signifikan terhadap kemampuan siswa dalam mengingat materi atau retensi siswa kelas eksperimen dan kontrol. Oleh karena itu dapat simpulkan bahwa model pembelajaran kooperatif STAD efektif terhadap retensi siswa kelas V.

Tabel 7 Daya Retensi Siswa

\begin{tabular}{ccccc}
\hline Kelas & Posttest 1 & Posttest 2 & Prosentase (\%) & Ket \\
\hline Eksperimen & 74,23 & 72,05 & 3,0 & Menurun \\
\hline Kontrol & 66,15 & 62,95 & 5,1 & Menurun \\
\hline
\end{tabular}




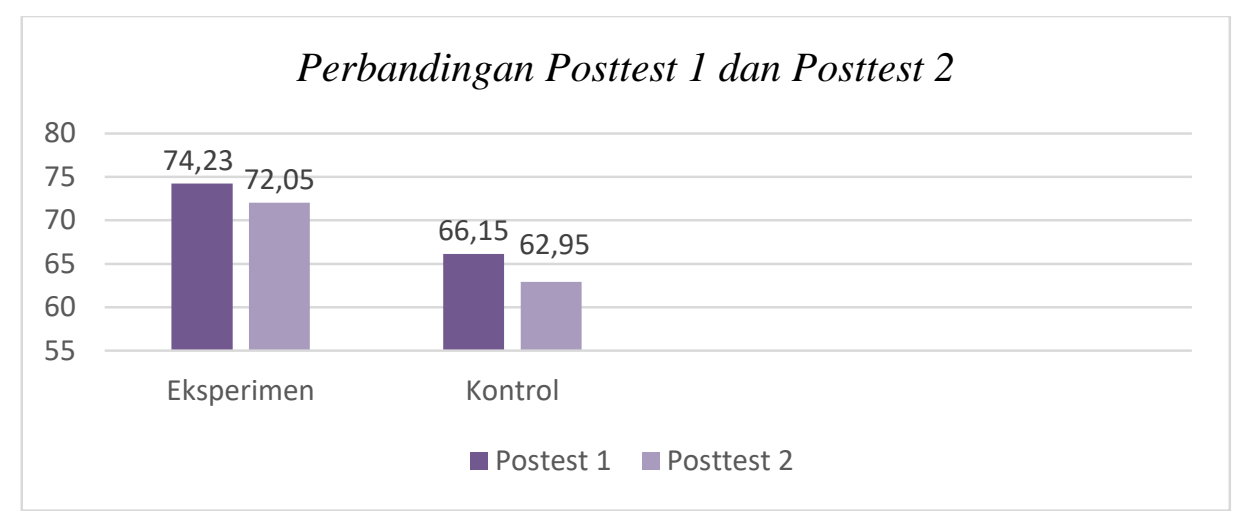

Gambar 1 Perbandingan Posttest 1 dan Posttest 2

Berdasarkan gambar 1 menunjukkan kemampuan kognitif siswa pada kelas eksperimen dan kontrol mengalami penurunan daya retensi siswa. Sebagai acuan pada nilai posttest 1 dan posttest 2 kelas eksperimen dan kelas kontrol. Hal ini menunjukkan bahwa penurunan daya retensi siswa kelas eksperimen lebih rendah dibandingkan penurunan daya retensi siswa kelas kontrol. Berdasarkan data ini dapat diperoleh dari penurunan nilai posttest 1 dan nilai posttest 2 pada masing-masing kelas. Siswa kelas eksperimen mengalami penurunan daya retensi sebesar $3 \%$, sedangkan siswa kelas kontrol mengalami penurunan daya retensi sebesar 5,1\%. Selisih antara retensi kelas eksperimen dan kelas kontrol sebesar 2,1\%. Dengan demikian, daya retensi siswa kelas eksperimen lebih tinggi dibandingkan daya retensi siswa kelas kontrol.

\section{PEMBAHASAN}

Hasil analisis statistik menunjukkan hasil yang signifikan model pembelajaran Kooperatif STAD terhadap hasil belajar kognitif siswa pada mata pelajaran IPS tematik terpadu. Hal ini menunjukkan bahwa model pembelajaran kooperatif STAD lebih efektif diterapkan pada pembelajaran IPS tematik terpadu. Selanjutnya, model pembelajaran kooperatif STAD memberikan dampak positif terhadap daya retensi siswa terhadap materi yang telah dibelajarkan.

Efektivitas model pembelajaran ini tidak terlepas dari lima langkah utama pembelajaran model STAD yang terdiri atas: 1) langkah pertama tahap persiapan; 2) langkah kedua tahap presentasi guru; 3) langkah ketiga tahap kerja kelompok; 4) langkah keempat tahap kuis individu; dan 5) langkah kelima penghargaan (Slavin, 2005).

Pada tahapan pertama, guru mempersiapkan siswa dalam sebelum melaksanakan proses pembelajaran. Pada tahap ini guru mempersiapkan siswa untuk mengikuti proses pembelajaran. Guru memberikan motivasi kepada siswa agar tertarik mengikuti proses pembelajaran. Selain itu, guru memberikan memberikan kata kunci terkait pembelajaran sebelumnya. Guru juga memberikan pertanyaan-pertanyaan terkait pembelajaran sebelumnya, dengan harapan siswa dapat mengingat materi yang telah dipelajari. Setelah siswa mampu mengingat materi sebelumnya, maka akan lebih mudah mengaitkan materi yang akan dipelajari. Setelah siswa memahami hal tersebut, guru menyampaikan tujuan pembelajaran kepada siswa. Melalui penyampaian tujuan pembelajaran maka siswa akan mengetahui materi yang akan dipelajarinya saat proses pembelajaran.

Pada tahap kedua, guru menyampaikan materi yang mengacu pada tujuan pembelajaran. Penyampaian materi tersebut bertujuan agar siswa dapat memahami materi-materi yang akan dipelajari saat proses pembelajaran. Selain itu, guru dapat 
menghantar siswa kepada materi-materi tertentu yang belum siswa pahami. Dengan demikian, siswa dapat belajar lebih mudah dalam mengikuti proses pembelajaran.

Pada tahap ketiga, guru mengakomodasi siswa untuk melaksanakan kerja kelompok. Siswa dikelompokkan menjadi beberapa kelompok yang terdiri atas 2-5 orang. Siswa diberikan LKS oleh guru. LKS tersebut digunakan untuk bekerja secara berkelompok. Bekerja secara kelompok merupakan kegiatan kolaborasi antara siswa dengan siswa lain. Kegiatan kolaborasi tersebut memungkinkan siswa untuk belajar secara tepat, efisien, dan belajar melalui pengalaman (Johnson \& Johnson, 1999). Pada kegiatan belajar secara kelompok melibatkan memory episodic siswa sehingga melekat pada memori jangka panjang (long-term memory). Memory episodic merupakan memori yang sangat penting dalam menyimpan kejadian-kejadian pada masa lampau (Solso, Maclin, \& Maclin, 2008). Menurut (Anyagh, 2006) pemilihan model pembelajaran yang tepat akan memberikan pengalaman belajar bagi siswa, sehingga mempermudah siswa untuk mengingat materi pelajaran dengan lebih efektif.

Pada tahap keempat, siswa diberikan kuis individu oleh guru. Pemberian kuis ini bertujuan untuk mengetahui perkembangan pengetahuan siswa terhadap materi yang dipelajari. Selain itu, pemberian kuis akan berfungsi sebagai kegiatan untuk melihat progress perkembangan pengetahuan siswa. Hasil kuis individu tersebut diakumulasikan untuk skor kelompok. Skor kelompok tersebut akan dijadikan ukuran nominasi kelompok yang memperoleh peringkat satu, dua, dan tiga.

Pada tahap kelima, pemberian reward kepada kelompok yang memperoleh nilai terbaik. Kelompok yang memperoleh skor tertinggi akan memperoleh reward dari guru. Reward pada penelitian ini berupa alat tulis. Pemberian alat tulis tersebut diharapkan akan memotivasi siswa untuk belajar lebih giat lagi.

\section{PENUTUP}

Hasil analisis data posttest 1 menggunakan uji t independent menunjukkan nilai $\mathrm{t}$ hitung $-3,73$ dengan nilai signifikansi. $0,00<0,05$ sehingga $\mathrm{H}_{0}$ ditolak. Hal ini menunjukkan bahwa terdapat perbedaan hasil belajar kognitif kelas eksperimen dan kelas kontrol. Dengan demikian, model pembelajaran kooperatif STAD efektif memberikan pengaruh terhadap hasil belajar kognitif siswa siswa kelas V Sekolah Dasar.

Hasil analisis data posttest 2 menggunakan uji t independent menunjukkan nilai nilai t hitung -3,65 dengan nilai signifikansi. 0,001 $<0,05$ sehingga $\mathrm{H}_{0}$ ditolak. Hal ini menunjukkan bahwa terdapat perbedaan retensi kelas eksperimen dan kelas kontrol. Dengan demikian, model pembelajaran kooperatif STAD efektif memberikan pengaruh terhadap retensi siswa siswa kelas V Sekolah Dasar.

Penurunan daya retensi siswa kelas eksperimen sebesar $3 \%$, sedangkan penurunan daya retensi siswa kelas kontrol sebesar $5,1 \%$. Selisih penurunan daya retensi antara kelas eksperimen dan kelas kontrol sebesar 2,1\%. Dengan demikian, kelas eksperimen lebih baik dibandingkan kelas kontrol dalam mempertahankan daya retensi.

\section{UCAPAN TERIMA KASIH}

Tim penulis mengucapkan terima kasih kepada Kemristekdikti yang telah memberikan dana hibah untuk melaksanakan penelitian. Ucapan terima kasih kepada STKIP PGRI Banjarmasin yang telah memfasilitasi penulis dalam melaksanakan penelitian. Ucapan terima kasih kepada dewan redaksi jurnal Mualimuna yang telah memfasilitasi penulis untuk menerbitkan jurnal penelitian. 


\section{DAFTAR PUSTAKA}

Anyagh, I. P. (2006). Effectof Formula Approach on Students' Achievement and Retention in Algebra. Unpublished Master's Thesis. Benue State University.

Hafid, H., \& Makkasau, A. (2013). Application Cooperative model type STAD (Student Teams Achievement Divison) in Increase Mastery of Student Learning Result of Grade VI Elementary School Kasi-Kassi Makasar. Research Journal of Science and IT Management, 27-36.

Johnson, D. w., \& Johnson, R. T. (1999). Learning Together and Alone: Cooperative, Competitive and Individualistic Learning. USA: Allyn and Bacon.

Peraturan Menteri Pendidikan dan Kebudayaan No. 22. (2016). Jakarta.

Rusman. (2015). Pembelajaran Tematik Terpadu. Jakarta : Rajawali Press.

Slavin, R. E. (2005). Cooperative Learning. Terjemahan oleh Yusron. Bandung: Nusa Media.

Solso, R. L., Maclin, O. H., \& Maclin, K. M. (2008). Cognitive Psychology 8 th edition. (Mikael Rahardanto \& Kritianto Batuaji, Trans). Jakarta: Erlangga.

Sugiyono. (2013). Metode Penelitian Pendidikan. Bandung: Alfabeta.

Suhanandji, \& Wasdopo, T. S. (2003). Pendidikan IPS. Surabaya: Insan Cendekia.

Thurston, A., Christie, D., Karagiannidou, E., Tolmie, A., Murray, P., \& Topping, K. (2010). Enhancing Outcomes in School Science for Pupils during Transition from Elementary School Using Cooperative Learning. Middle grades research journal, 5(1). 19-32.

Undang-Undang Nomor 20 Tahun 2003 tentang Sistem Pendidikan Nasional. (2003).

Wahidmurti. (2017). Metodologi Pembelajaran IPS. Yogjakarta: Ar-Ruzz Media.

Widyastono, H. (2013). Pengembangan Kurikulum Di Era Otonomi Daerah. Jakarta: Bumi Aksara. 